\title{
The discovery of a novel Bromodomain and Extra Terminal domain (BET) Protein inhibitor, I- BET282E, suitable for clinical progression.
}

Katherine L. Jones, ${ }^{* 1}$ Dominic M. Beaumont, ${ }^{1}$ Sharon G. Bernard, ${ }^{1}$ Rino A. Bit, ${ }^{1}$ Simon P.

Campbell, ${ }^{1}$ Chun-wa Chung, ${ }^{1}$ Leanne Cutler, ${ }^{1}$ Emmanuel H. Demont, ${ }^{1}$ Kate Dennis ${ }^{1}$, Laurie

Gordon, ${ }^{1}$ James R. Gray, ${ }^{1}$ Michael V. Haase, ${ }^{1}$ Antonia J. Lewis, ${ }^{1}$ Scott McCleary, ${ }^{1}$ Darren J.

Mitchell, ${ }^{1}$ Susanne M. Moore, ${ }^{1}$ Nigel Parr,${ }^{1}$ Olivia J. Robb,${ }^{1}$ Nicholas Smithers,${ }^{1}$ Peter E. Soden, ${ }^{1}$

Colin J. Suckling, ${ }^{2}$ Simon Taylor, ${ }^{1}$ Ann L. Walker, ${ }^{1}$ Robert J. Watson, ${ }^{1}$ Rab K. Prinjha. ${ }^{1}$

${ }^{1}$ GlaxoSmithKline, Medicines Research Centre, Gunnels Wood Road, Stevenage, Hertfordshire,

SG1 2NY, U.K. ${ }^{2}$ Department of Pure \& Applied Chemistry, University of Strathclyde, Glasgow,

G1 1XL. 
Supporting Information 


\section{Table of contents}

S3 Crystallography data collection and co-ordinates

S6 Biochemical and Biophysical characterization of I-BET282 (32)

- BET bromodomain FRET potency data for I-BET282 (32)

- ITC of I-BET282 (32) with BRD4 and CREBBP

- $\mathrm{T}_{\mathrm{m}}$ Selectivity Determination

S10 BROMOscan® - Bromodomain Assay Panel

S11 X-Ray Powder Diffraction (XRPD)

S12 HPLC traces of key compounds

S14 ${ }^{1} \mathrm{H}$ NMR, ${ }^{13} \mathrm{C}$ NMR and chiral HPLC traces for I-BET282 (32) 


\section{Crystallography data collection and co-ordinates}

BRD4-BD1/ I-BET282 was co-crystallized in sitting drops using a 96 well MRC plate at $20{ }^{\circ} \mathrm{C}$.

Crystals grown with a well solution of $200 \mathrm{mM} \mathrm{CaCl}_{2}, 25 \%$ PEG4K, $100 \mathrm{mM}$ Tris $\mathrm{HCl}, \mathrm{pH} 8.5$

were cryoprotected using well solution with $20 \%$ ethylene glycol prior to flash freezing in liquid

nitrogen. Data from a single crystal was collected $100 \mathrm{~K}$ on an in-house RIGAKU FR-E+

SUPERBRIGHT/Saturn A200 detector/ACTOR robotic system and processed using D*TREK.

A molecular replacement solution was determined with a previously collected in house structure.

Manual model building was performed using COOT and refined using REFMAC within the

CCP4 software suite. There was clear difference density for the ligand in the acetylated lysine

binding site, allowing the ligand to be unambiguously modelled.

Figure S1. X-ray OMIT map (Fo-Fc) for I-BET282 32 binding in BRD4-BD1 (PDB: 7O18) 


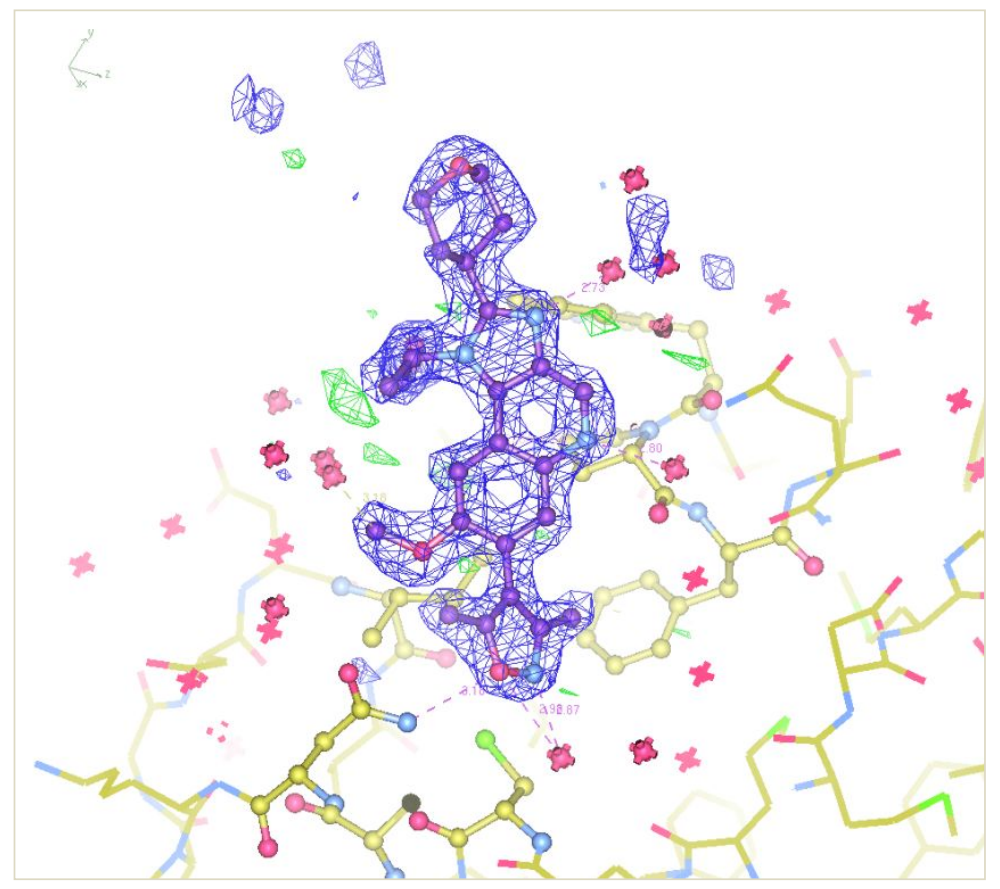

OMIT difference map (Fo-Fc), after removal of the I-BET282 32 compound from the final X-

ray structure model, is shown. The map is contoured at +/- 3 sigma, in blue and green respectively. The modelling of the binding mode of I-BET282 is unambiguous with all elements of the molecule clearly defined.

Table S1. Data collection and refinement statistics for I-BET282 (32) with BRD4-BD1

\begin{tabular}{|l|l|}
\hline & BRD4-BD1 I-BET282 \\
\hline Data collection & \\
\hline Space group & $\mathrm{P} 2{ }_{1}{ }_{1} 2_{1}$ \\
\hline Cell dimensions & \\
\hline
\end{tabular}




\begin{tabular}{|c|c|}
\hline$a, b, c(\AA)$ & $42.55,46.29,61.41$ \\
\hline$\alpha, \beta, \gamma\left(^{\circ}\right)$ & $90.0,90.0,90.0$ \\
\hline Resolution $(\AA)$ & $36.97-1.7(1.76-1.7)^{a}$ \\
\hline$R_{\text {merge }}$ & $0.043(0.119)$ \\
\hline$l / \sigma l$ & $23.2(5.6)$ \\
\hline Completeness (\%) & $93.9(61.9)$ \\
\hline Redundancy & $3.92(2.15)$ \\
\hline \multicolumn{2}{|l|}{ Refinement } \\
\hline Resolution $(\AA)$ & $36.97-1.7$ \\
\hline No. Reflections (uniq) & $51029(13015)$ \\
\hline$R_{\text {work } /} R_{\text {free }}$ & $0.170 / 0.212$ \\
\hline No. atoms & 1290 \\
\hline Protein & 1063 \\
\hline Ligand/ion & $33 / 8$ \\
\hline Water & 186 \\
\hline \multicolumn{2}{|l|}{ B-factors } \\
\hline Protein & 13.2 \\
\hline Ligand/ion & $15.6 / 34.1$ \\
\hline Water & 28.2 \\
\hline \multicolumn{2}{|l|}{ R.m.s deviations } \\
\hline Bond lengths $(\AA)$ & 0.006 \\
\hline
\end{tabular}




\section{\begin{tabular}{|l|l|} 
Bond angles $\left({ }^{\circ}\right)$ & 1.391
\end{tabular}}

ahighest resolution shell 
Biochemical and Biophysical characterization of I-BET282 (32)

BET bromodomain FRET potency data for I-BET282 (32)

Table S2. TR-FRET assay data for binding of I-BET282 to the first and second bromodomains of the BET proteins BRD2, BRD3, BRD4 and BRDt.

\begin{tabular}{|l|l|l|}
\hline & BD1 & BD2 \\
\hline BRD2 & 7.2 & 7.1 \\
\hline BRD3 & 7.6 & 7.7 \\
\hline BRD4 & 7.4 & 6.9 \\
\hline BRDt & 7.1 & 6.4 \\
\hline
\end{tabular}

${ }^{a}$ Expressed as a mean of at least two experimental replicates.

ITC of I-BET282 (32) with BRD4 and CREBBP

BRD4

6His-BRD4 (1-477) (also referred to as BRD4-BD12) was titrated into I-BET282 32 at $25{ }^{\circ} \mathrm{C}$

using a buffer of $50 \mathrm{mM}$ Hepes $\mathrm{pH} 7.4,150 \mathrm{mM} \mathrm{NaCl}$. The binding isotherms were best 
characterized by fitting to a binding model with a single affinity constant suggesting the $N$ - and $C$-terminal bromodomains (BD1, BD2 respectively) affinities that cannot be readily differentiated at the micromolar concentrations used in ITC. The parameters determined using this standard single affinity model are given below.

Table S3. Brd4 ITC parameters

\begin{tabular}{|l|l|l|l|l|l|l|l|l|}
\hline Expt & Cell & Syringe & $\begin{array}{l}\text { Cell } \\
\text { Conc } \\
\text { Conc }\end{array}$ & $\begin{array}{l}\text { Syringe } \\
(\mathrm{KM})\end{array}$ & $\begin{array}{l}\mathrm{K}_{\mathrm{D}} \\
(\mathrm{kcal} / \mathrm{mol})\end{array}$ & $\begin{array}{l}\Delta \mathrm{S} \\
(\mathrm{cal} / \mathrm{mol})\end{array}$ & $\mathrm{N}$ \\
\hline 1 & 32 & Brd4 (1-477) & $10 \mu \mathrm{M}$ & $106 \mu \mathrm{M}$ & $\begin{array}{l}39 \mathrm{nM} \\
\pm 7\end{array}$ & $-7.8 \pm 0.1^{\mathrm{a}}$ & 7.7 & $\begin{array}{l}2.36 \\
0.01\end{array}$ \\
\hline 2 & 32 & Brd4 (1-477) & $10 \mu \mathrm{M}$ & $106 \mu \mathrm{M}$ & $\begin{array}{l}56 \mathrm{nM} \\
\pm 16\end{array}$ & $-14.5 \pm 0.3$ & -15.6 & $\begin{array}{l}2.61 \quad \pm \\
0.01\end{array}$ \\
\hline
\end{tabular}

aSignificant baseline drift may have compromised the enthalpy and entropy values, but has little effect on $\mathrm{N}$ and $\mathrm{K}_{\mathrm{D}}$ as the repeat titration confirms.

Summary: I-BET282 32 binds to BRD4(1-477) with a 2:1 stoichiometry, consistent with the binding of one ligand molecule at each of the bromodomain sites. At the micromolar concentrations necessary for the ITC experiments the binding isotherms are best fitted using a single affinity constant determined to be $47.5 \pm 25 \mathrm{nM}$ for I-BET282. The binding is enthalpy driven. 
Titration of I-BET282 32 into bromodomain of CBP at $25^{\circ} \mathrm{C}$ in $50 \mathrm{mM}$ Hepes, pH7.4, 150 $\mathrm{mM} \mathrm{NaCl}$ using a Microcal VPITC instrument. The resulting binding isotherm was fitted to a standard 1:1 binding model to give the below parameters:

Table S4. CBP ITC parameters

\begin{tabular}{|l|l|l|l|l|l|l|l|l|}
\hline Cell & Syringe & $\begin{array}{l}\text { Cell } \\
\text { Conc }\end{array}$ & $\begin{array}{l}\text { Syringe } \\
\text { Conc }\end{array}$ & $\begin{array}{l}\mathrm{KA} \\
(\mathrm{M})\end{array}$ & $\begin{array}{l}\mathrm{K}_{\mathrm{D}} \\
(\mu \mathrm{M})\end{array}$ & $\begin{array}{l}\Delta \mathrm{H} \\
(\mathrm{kcal} / \mathrm{mol})\end{array}$ & $\begin{array}{l}\Delta \mathrm{S} \\
(\mathrm{cal} / \mathrm{mol})\end{array}$ & $\mathrm{N}$ \\
\hline $\mathrm{CBP}$ & 32 & $10 \mu \mathrm{M}$ & $130 \mu \mathrm{M}$ & $\begin{array}{l}5.76 \pm \\
0.56 \mathrm{e} 5\end{array}$ & $\begin{array}{l}1.73 \pm \\
0.17\end{array}$ & $-10.6 \pm 0.3$ & -9.4 & $\begin{array}{l}0.94 \pm \\
0.02\end{array}$ \\
\hline
\end{tabular}

Summary: The isothermal titration calorimetry (ITC) study is consistent with the binding of I-

BET282 32 to the single bromodomain of CBBP with a 1:1 stoichiometry, $\mathrm{K}_{\mathrm{D}}$ of $1.7 \pm 0.17 \mu \mathrm{M}$ and an enthalpy change of $\Delta \mathrm{H}_{\mathrm{A}}$ of $-10.6 \pm 0.3 \mathrm{kcal} / \mathrm{mol}$.

\section{$\mathrm{T}_{\mathrm{m}}$ Selectivity Determination}


An increase in thermal stability (positive $\Delta \mathrm{T}_{\mathrm{m}}$ ) can be observed when compounds bind to proteins. Samples of proteins $(0.1-0.3 \mathrm{mg} / \mathrm{mL})$ in the presence of $100 \mu \mathrm{M}$ I-BET282 32 in a buffer of $10 \%$ glycerol / $90 \%$ phosphate buffer saline were prepared. Denaturation was visualized by addition of the fluorescent dye, Sypro orange, at a 1:1000 dilution which displays increased fluorescence when hydrophobic patches are exposed as a consequence of protein unfolding. Temperature ramps of either $4-94{ }^{\circ} \mathrm{C}$ or $30-72{ }^{\circ} \mathrm{C}$ were used depending on instrumentation. The data was fitted using a simple Boltzmann equation. Data from at least two replicates are shown in the table below.

Table S5. $\mathrm{T}_{\mathrm{m}}$ Selectivity data for I-BET282 (32)

\begin{tabular}{|c|c|}
\hline Protein & Average $\Delta \mathrm{T}_{\mathrm{m}}{ }^{\mathrm{a}}\left({ }^{\circ} \mathrm{C}\right)$ \\
\hline BRD4-BD12 & 9.9 \\
\hline ATAD2 & $<1$ \\
\hline PCAF & $<1$ \\
\hline SP140 & $<1$ \\
\hline BAZ2B & $<1$ \\
\hline CREBBP & 3.4 \\
\hline
\end{tabular}

${ }^{\text {aA }}$ standard error of $1{ }^{\circ} \mathrm{C}$ is typically used.

I-BET282 (32) shows strong binding to the tandem bromodomain of BRD4-BD12 $\left(\Delta \mathrm{T}_{\mathrm{m}}=9.9\right.$

$\left.{ }^{\circ} \mathrm{C}\right)$ and also significantly, but reduced, binding to the bromodomain of CREBBP $\left(\Delta \mathrm{T}_{\mathrm{m}}=3.4\right.$ 
$\left.{ }^{\circ} \mathrm{C}\right)$. This is consistent with data from isothermal titration calorimetry (ITC) studies. No detectable binding to the bromodomains of ATAD2, BAZ2B, PCAF or SP140 can be detected using this technique. 


\section{BROMOscan® - Bromodomain Assay Panel}

I-BET282 (32) was profiled in dose response format against a wide range of bromodomaincontaining proteins using the BROMOscan® platform available at DiscoverX (Eurofins).

Table S6. Selectivity data for I-BET282 (32) using the BROMOscan® platform

\begin{tabular}{|c|c|c|c|}
\hline Bromodomain & $\boldsymbol{K}_{\mathrm{d}}(\mathbf{n M})^{\mathrm{a}}$ & Bromodomain & $\boldsymbol{K}_{\mathrm{d}}(\mathbf{n M})^{\mathrm{a}}$ \\
\hline ATAD2A & $>30000$ & BRDT(2) & 140 \\
\hline ATAD2B & $>30000$ & BRPF1 & $>30000$ \\
\hline BAZ2A & $>30000$ & BRPF3 & $>30000$ \\
\hline BAZ2B & $>30000$ & CREBBP & 2600 \\
\hline BRD1 & $>30000$ & EP300 & 3000 \\
\hline BRD2(1) & 24 & FALZ & $>30000$ \\
\hline BRD2(2) & 22 & PBRM1(2) & $>30000$ \\
\hline BRD3(1) & 8.1 & TAF1(2) & 20000 \\
\hline BRD3(2) & 10 & TAF1L(2) & $>30000$ \\
\hline BRD4(1) & 15 & TRIM24(PHD,BROMO) & $>30000$ \\
\hline BRD4(2) & 35 & TRIM33(PHD,BROMO) & $>30000$ \\
\hline BRD9 & $>30000$ & WDR9(2) & $>30000$ \\
\hline BRDT(1) & 58 & & \\
\hline
\end{tabular}

aData is a single experimental replicate. 


\section{X-Ray Powder Diffraction (XRPD)}

The data were acquired on a PANalytical X'Pert Pro powder diffractometer, model PW3040/60 using an X'Celerator detector. The acquisition conditions were: radiation: $\mathrm{Cu} \mathrm{Ka,}$ generator tension: $40 \mathrm{kV}$, generator current: $45 \mathrm{~mA}$, start angle: $2.0^{\circ} 2 \theta$, end angle: $40.0^{\circ} 2 \theta$, step size: $0.0167^{\circ} 2 \theta$, time per step: 31.75 seconds. The sample was prepared by mounting a few milligrams of sample on a silicon wafer (zero background plate), resulting in a thin layer of powder.

Figure S2. I-BET282 Form 1

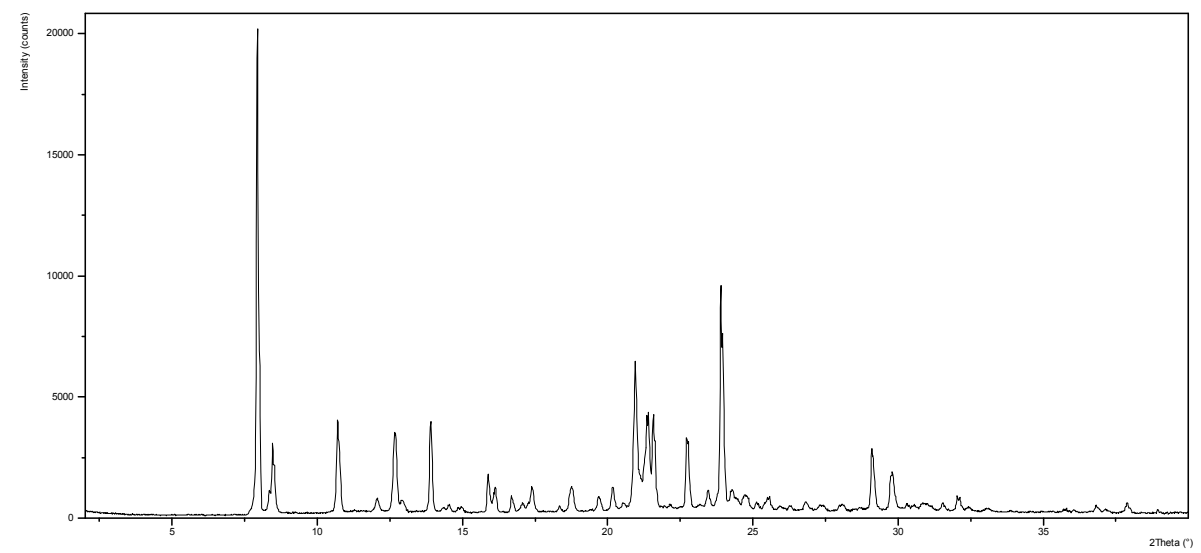

Figure S3. I-BET282 Form 2 


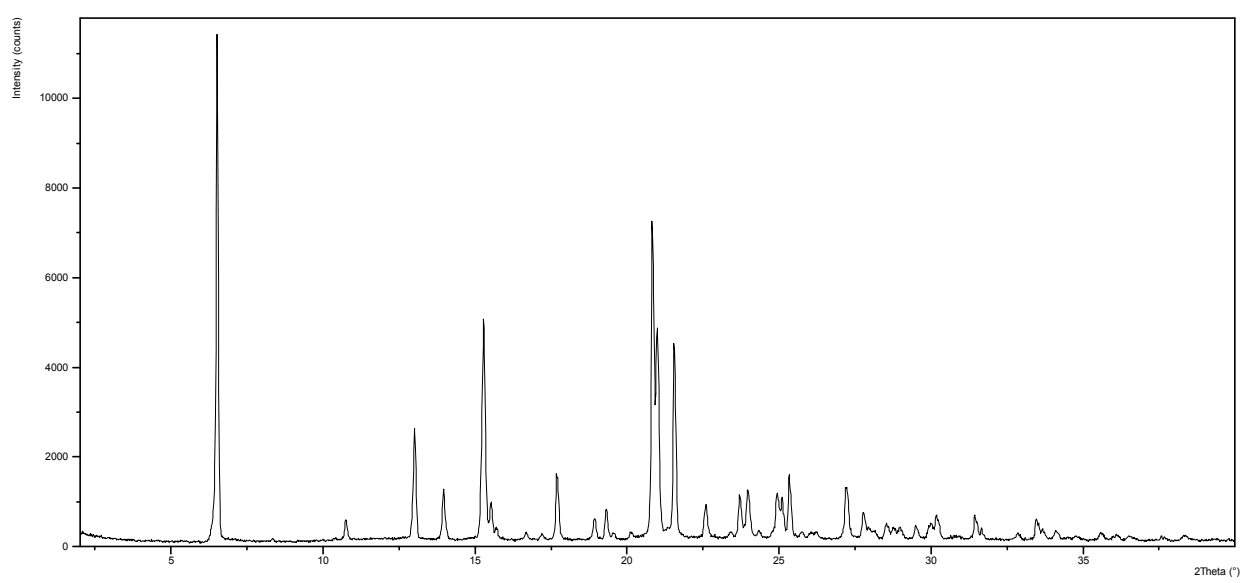

\section{HPLC traces of key compounds}

All compounds have purity of $100 \%$, as indicated by the Area \%Total value associated with the peak numbers below the HPLC trace.

\section{Compound 25}

UV Detector: TIC

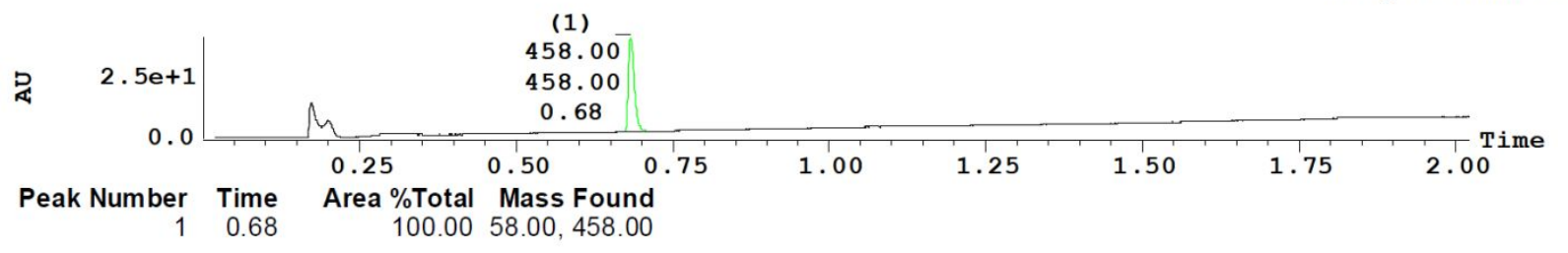

\section{Compound 32}

3: UV Detector: TIC

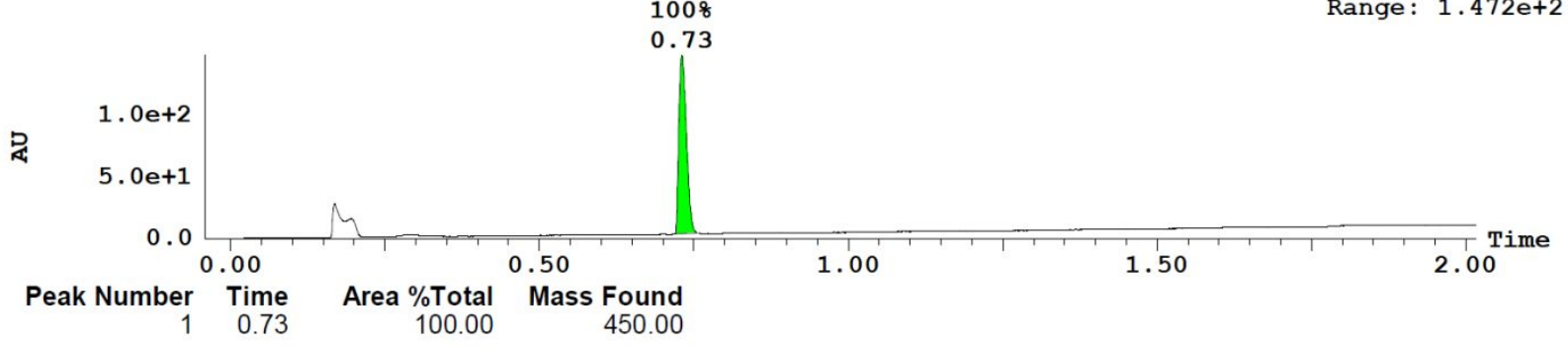

Compound 35 
UV Detector: TIC

6. $529 \mathrm{e}+1$

Range: $6.528 e+1$

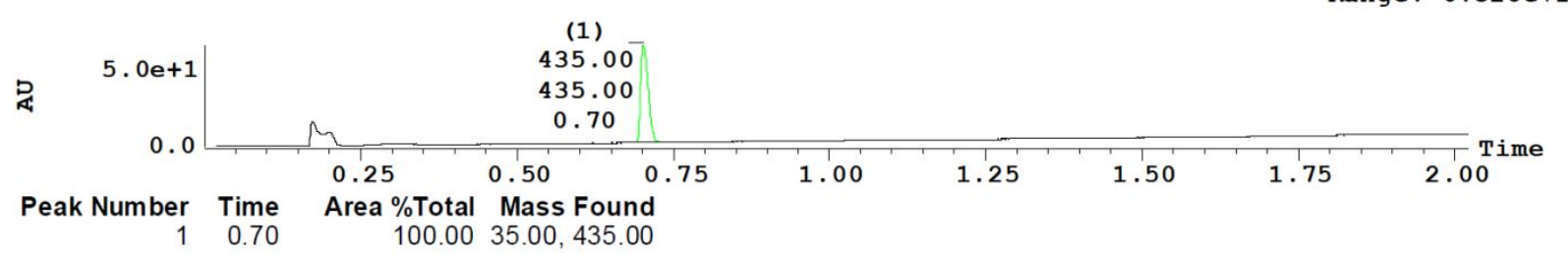

Compound 37

UV Detector: TIC

Range: $\begin{array}{r}9.771 e+1 \\ 9.771 e+1\end{array}$

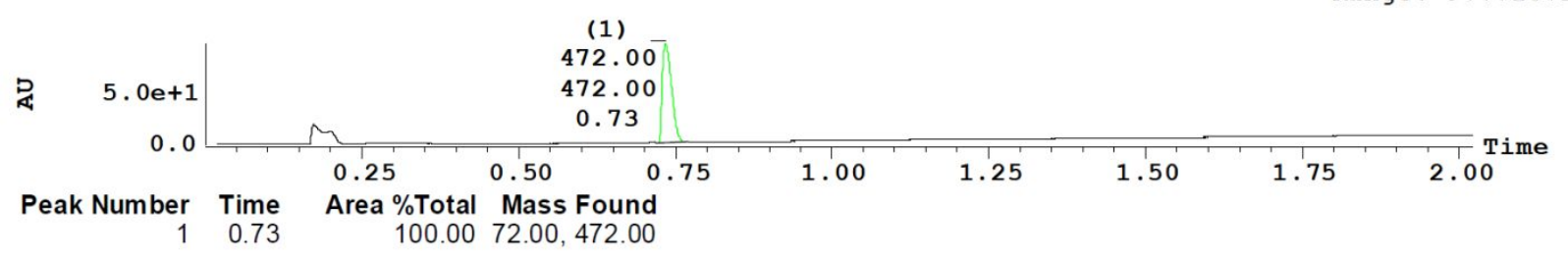

\section{Compound 75}

3: UV Detector: TIC

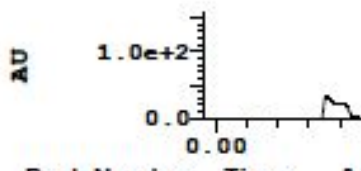

$\begin{array}{rr}\text { Peak Number } & \text { Time } \\ 3 & 0.73\end{array}$

Area \% Total \% Total 


\section{${ }^{1} \mathrm{H}$ NMR, ${ }^{13} \mathrm{C}$ NMR and chiral HPLC traces for I-BET282 (32)}

${ }^{1} \mathrm{H}$ NMR spectrum of compound 32, taken at $393 \mathrm{~K}$ (peaks not resolved at room temperature).

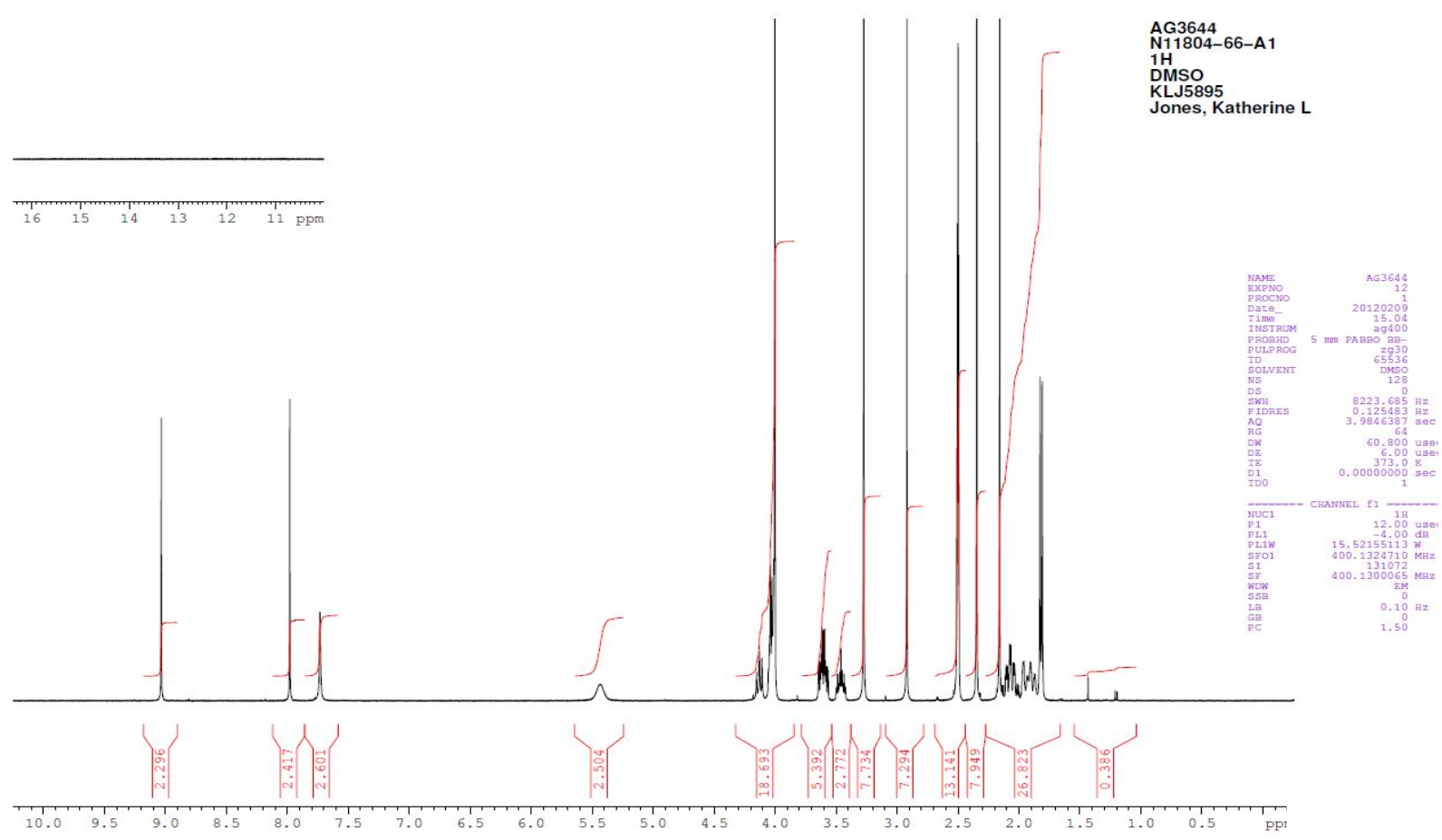


${ }^{13} \mathrm{C}$ NMR spectrum of compound 32

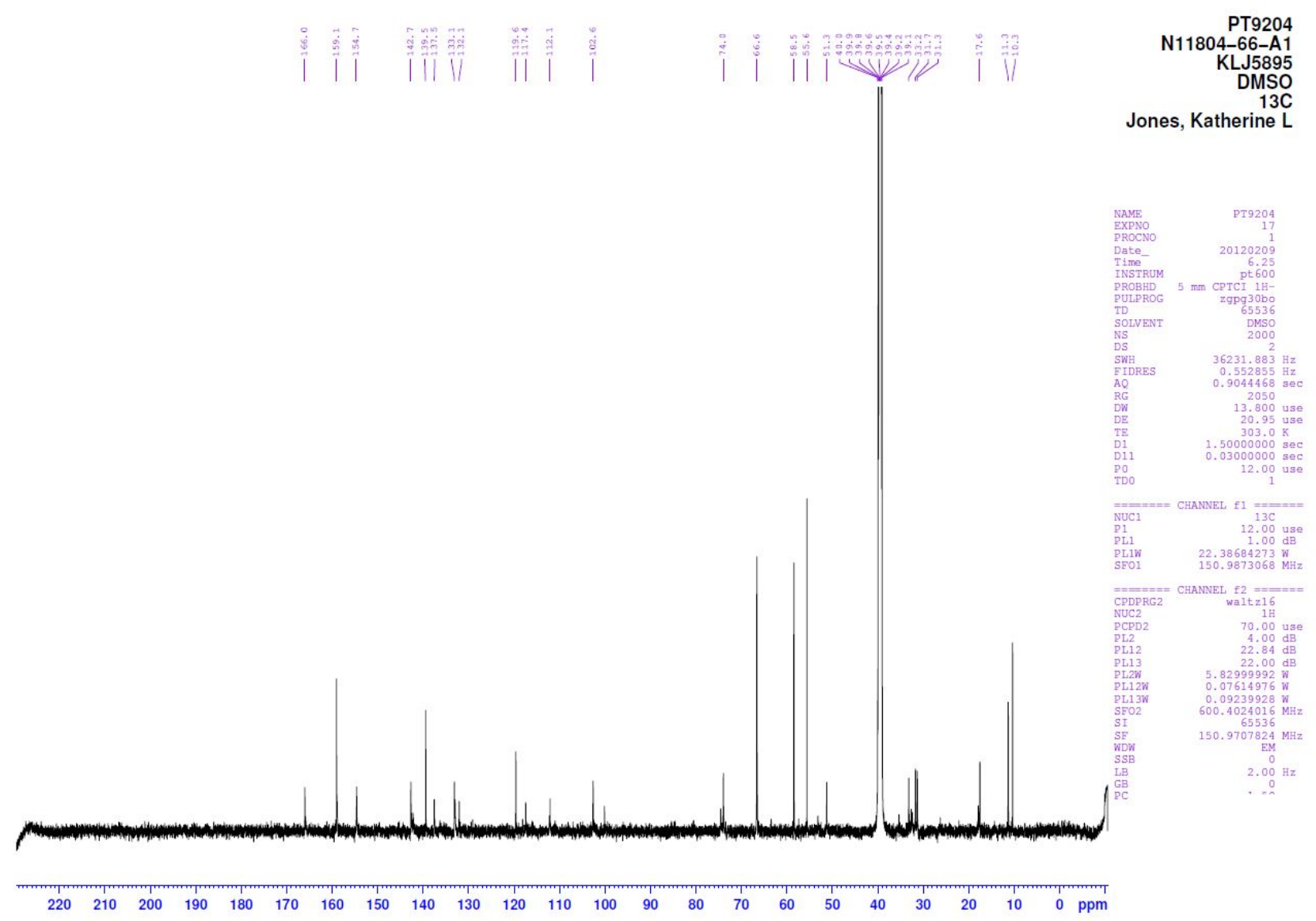


Analytical chiral HPLC traces of I-BET282 (compound 32) labelled "N11804-66-A1", and the same sample spiked with its enantiomer compound 31 labelled "N20235-90-1".
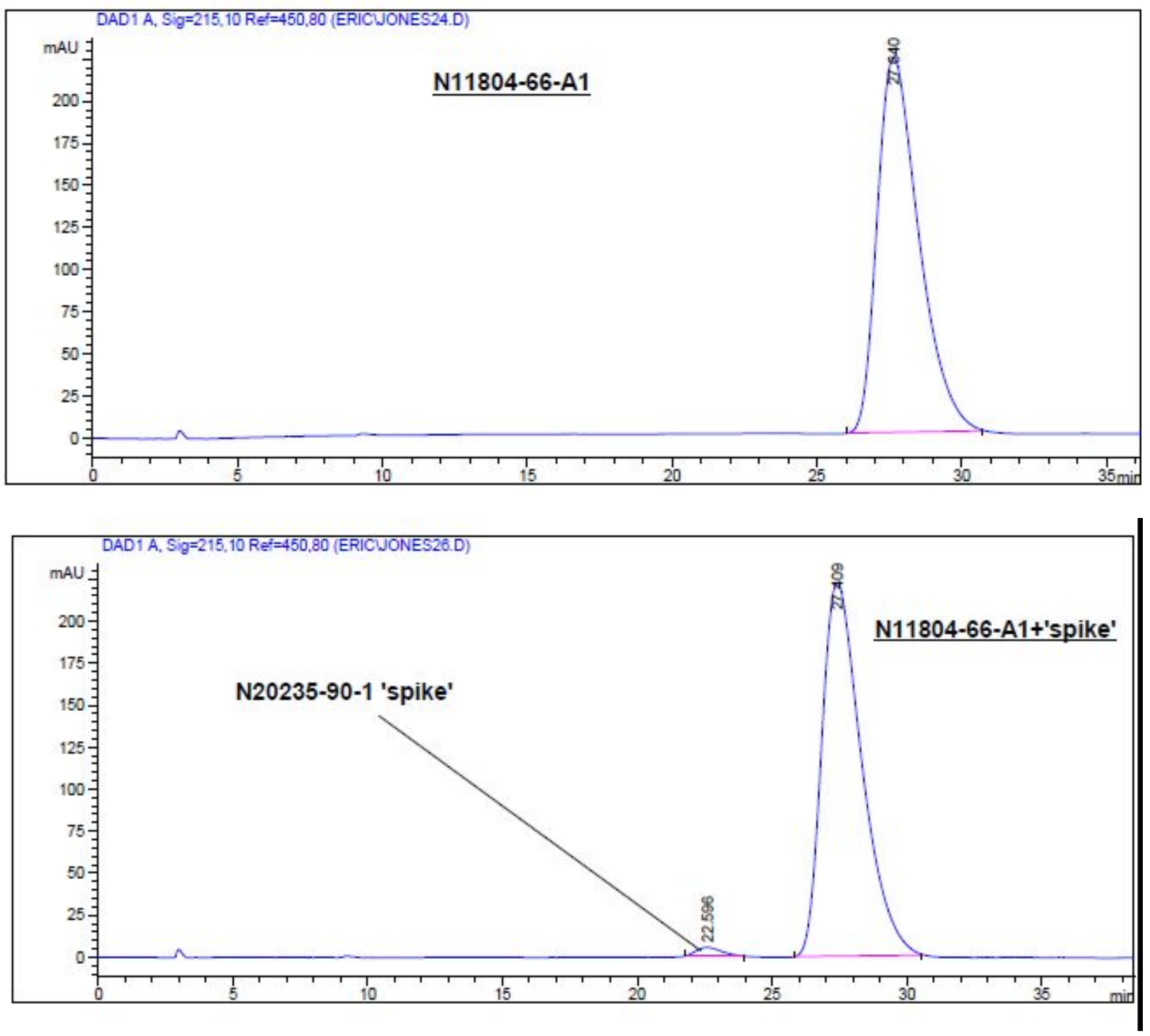